\title{
Article \\ Mobile Off-Grid Energy Generation Unit for Temporary Energy Supply
}

\author{
Anatolijs Borodinecs (D), Deniss Zajecs, Kristina Lebedeva * and Raimonds Bogdanovics (D)
}

Citation: Borodinecs, A.; Zajecs, D.; Lebedeva, K.; Bogdanovics, R. Mobile Off-Grid Energy Generation Unit for Temporary Energy Supply. Appl. Sci. 2022, 12, 673. https://doi.org/ 10.3390/app12020673

Academic Editor: Andreas Sumper

Received: 22 November 2021

Accepted: 7 January 2022

Published: 11 January 2022

Publisher's Note: MDPI stays neutral with regard to jurisdictional claims in published maps and institutional affiliations.

Copyright: () 2022 by the authors Licensee MDPI, Basel, Switzerland. This article is an open access article distributed under the terms and conditions of the Creative Commons Attribution (CC BY) license (https:// creativecommons.org/licenses/by/ $4.0 /)$.

\begin{abstract}
Department of Heat Engineering and Technology, Riga Technical University, LV-1048 Riga, Latvia; anatolijs.borodinecs@rtu.lv (A.B.); deniss.zajecs@rtu.lv (D.Z.); raimonds.bogdanovics@rtu.lv (R.B.)

* Correspondence: kristina.lebedeva@rtu.lv
\end{abstract}

\begin{abstract}
Temporary structures are being extensively used by emergency services (rescue, disaster relief, military response units), and other end-users requiring temporary mobile off-grid energy solutions for different purposes (event organization, vacation homes, summer camps, etc.). Yet energy systems for these purposes largely remain fossil-based (such as diesel generators). Although such energy systems are inexpensive, they are carbon intensive and inefficient. This study presents a methodology of simulating temporary shelter with access to an energy supply system through a mobile energy unit with renewable (PV) power supply systems to ensure on-site electricity production, as well as heating/cooling and ventilation. Digital modeling simulations have been performed for a simulated temporary shelter in different climate conditions incorporating different combinations of electricity generation systems with a fossil fuel-based solution and a PV system, using TRNSYS software. Study results show that the operation of a mobile energy generation unit can operate HVAC systems and generate electricity for temporary shelter occupants in off-grid solutions. The modeling results show that the use of a mobile energy generation unit can significantly reduce diesel consumption in temporary shelters from 54\% annually (in Riga, Latvia) to $96 \%$ annually (in Jerusalem, Israel). Furthermore, the output of PV-generated electricity is higher (in most cases) than the consumed electricity amount.
\end{abstract}

Keywords: thermal comfort; ventilation; air condition; HVAC; off-grid energy systems; temporary structures

\section{Introduction}

The latest COVID-19 spread has highlighted the importance of mobile energy supply systems for temporary hospitals, mobile testing laboratories, and first aid services, as well as for self-isolation units. Despite the ongoing COVID-19 pandemic, a gradual recovery is already taking place in many countries, meaning the return to such activities as outdoor festivals, summer camps and other outdoor recreation events. These activities usually take place in temporary tents without any ventilation.

Quickly deployable sustainable temporary structures provide ventilation and adequate indoor quality and comfort conditions for people who have to be isolated or treated (mobile hospitals) or for those who have to stay in quarantine during an epidemic or pandemic. Temporary structures have been widely used on various occasions since the beginning of the COVID-19 outbreak as a low-cost and fast solution to accommodate the growing number of patients [1].

Quickly deployable energy supply systems can also be used for setting up refugee camps (shelters). About 82.4 million people worldwide were forcibly displaced by the end of 2020 [2]. There are around 900 registered refugee camps, and supposedly around 500 unregistered refugee camps worldwide [3].

In addition to refugee shelters, current data estimates show that there are around 500 temporary military camps deployed across the world. About 20,000 troops around the world are currently deployed in NATO missions [4]. 
Energy consumption in such campuses (refugee camps, military camps, etc.) is much higher in comparison to regular buildings, as the building envelope has a crucial role in maintaining heat balance and preserving heat loss from the building, accounting for up to $60 \%$ of building thermal performance [5], while in temporary shelters and tents the envelope oftentimes consist of light material with little to no insulation and protection from outdoor conditions. For instance, a recent study suggested that energy consumption in military facilities significantly exceeds that of residential buildings, mainly due to the poor thermal properties of military building stock [6].

Some sources suggest that the US military spends about $\$ 20.2$ billion annually for air conditioning in Iraq and Afghanistan missions [7]. That amount included the cost of the fuel and the entire infrastructure involved in the delivery of the fuel to military camps.

There are NATO initiatives in place on energy consumption in deployable military camps (tents) [8]. Tents are deemed as the most easily deployable solution. According to NATO Secretary General's Annual Report 2019 [9], the energy monitoring and camp simulation for energy efficiency is one of the modern-day challenges in overall energy security.

In any of the aforementioned cases, temporary infrastructure is rapidly created to adapt to the enormous and quick influx of migrants or affected humans in need of immediate shelter and services such as communications, short-term hospitals, lighting, cooling of medicines, hot water and sterilization, all of which require energy [10-12]. Temporary camps are often converted into permanent settlements with inadequate long-term planning for operations and maintenance [13]. The main results of the study [14] show that about 7 million displaced people have electricity for $4 \mathrm{~h}$ a day in temporary camps. However, energy supply in displaced conditions is usually restricted to minimum survival requirements, with an estimated $90 \%$ of displaced people worldwide not having adequate access to electricity [15]. Due to the lack of funding and unsustainability of clean energy policies and practices in temporary refugee camps, current energy supply methods in these types of camps are ineffective, insecure for users and detrimental to the environment [10]. As the number of temporary camps and their longevity increases, there is a growing interest in renewable based energy supply systems that can improve access to energy and human comfort [15]. Renewable energy sources alone in the off-grid areas cannot currently ensure a sustainable supply of energy due to their inconsistent availability and strong dependence on environmental conditions [10]. Electricity supply in refugee camps is restricted to a critical HVAC system and electricity supply operation usually powered by diesel fuel generators $[16,17]$. Currently, the most widely used renewable energy source is solar energy - it is safe, clean and easy to use, therefore it has become one of the most suitable energy sources that can be used in various fields and can be an alternative to fossil energy sources [18-22]. Many studies offer mobile PV systems solutions for autonomous electricity generation [23-26]. With regard to temporary shelters, electricity is usually provided by off-grid solutions (diesel fuel generators), which are not a sustainable energy supply because of their dependence on fuel availability. Although there are no accurate reports on energy consumption data in refugee camps, the United Nations High Commissioner for Refugees (UNHCR) estimates that the annual expenditure on diesel fuel to produce electricity is more than $\$ 35$ million [27].

Research [10] has provided examples of the energy related costs for two refugee camps in Burkina Faso and Kenya (see Table 1).

These numbers show the need for safer, cleaner and more cost-effective access to energy. Efficient energy access in temporary structures is one of the ways to achieve the 2030 Agenda for Sustainable Development Goals [28], adopted by all United Nations Member States in 2015, specifically the third goal: good health and well-being (by means of comfortable microclimate in temporary camps); the fourth goal: quality education (by providing electricity for lighting); and the seventh goal: affordable and clean energy (by sustainable energy access). 
Table 1. The energy related costs for refugee camps.

\begin{tabular}{ccc}
\hline & Goudoubo in Burkina Faso & Dadaab in Kenya \\
\hline Population & 10,327 & 356,014 \\
\hline $\begin{array}{c}\text { Costs (for electricity } \\
\text { generation with diesel fuel) }\end{array}$ & $31.5 \mathrm{k} \$ /$ year & $2.3 \mathrm{M} \$ /$ year \\
\hline $\begin{array}{c}\text { Energy-related costs in the } \\
\text { global budget }\end{array}$ & $8 \%$ & $20 \%$ \\
\hline $\begin{array}{c}\text { Energy consumed per } \\
\text { household }\end{array}$ & $\begin{array}{c}10.6 \$ / \text { month } \\
\text { (about 5-7\% of total } \\
\text { household earnings) }\end{array}$ & $\begin{array}{c}17.20 \$ / \text { month } \\
\text { (about 24\% of total } \\
\text { household earnings) }\end{array}$ \\
\hline
\end{tabular}

For successful implementation of expanding sustainable energy solutions in temporary shelters, the current paper presents a mobile energy unit with a renewable energy (PV) system for energy generation and HVAC systems operation. The presented solution is quickly deployable and can be adapted to future shelters/camps, for example, increasing the electricity needs. The developed working prototype is assembled on the basis of a car trailer and can be towed by a regular sized vehicle.

\section{Materials and Methods}

The developed mobile energy generation unit described in this paper consists of eight photovoltaic (PV) batteries for power generation connected to an inverter and electricity storage battery. The generated electricity is converted by a heat pump to heat or cool air for the heating/conditioning supply of temporary structures. Exhaust air heat recovery devices are used to increase the overall efficiency of the system and to ensure the adequate air hygiene and occupants' comfort in temporary shelters. Heat recovery is an integral part of modern energy efficient HVAC systems [29,30]. As an auxiliary source of energy generation (in case there is not enough solar resources), a diesel generator is provided to extend the autonomy of mobile energy generation unit. The operation control of the mobile energy generation unit is implemented by energy management controller connected via the Internet that can be operated remotely. The visualization, scheme and technical characteristics of the mobile energy generation unit are shown in Figures 1 and 2 and Table 2.
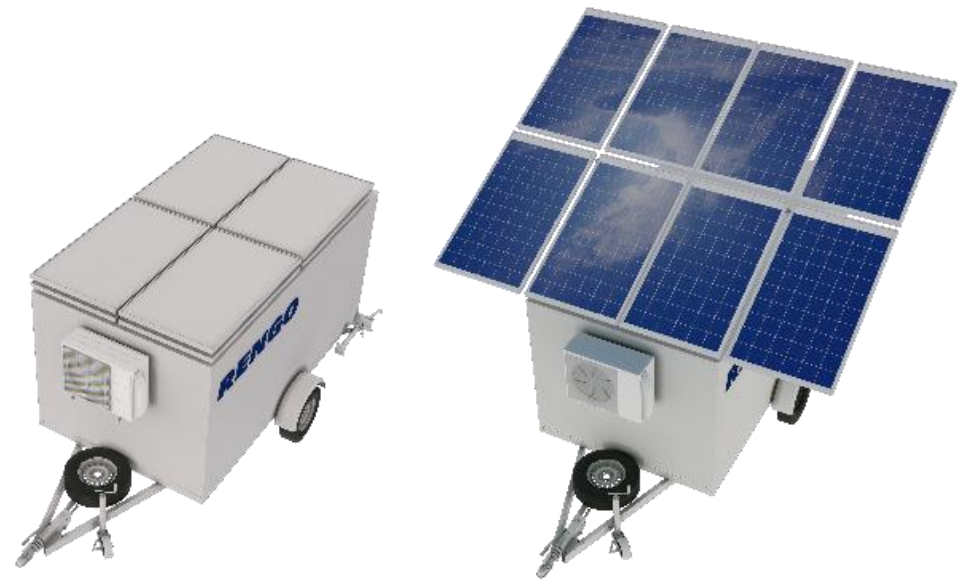

Figure 1. Visualization of mobile energy generation unit. 


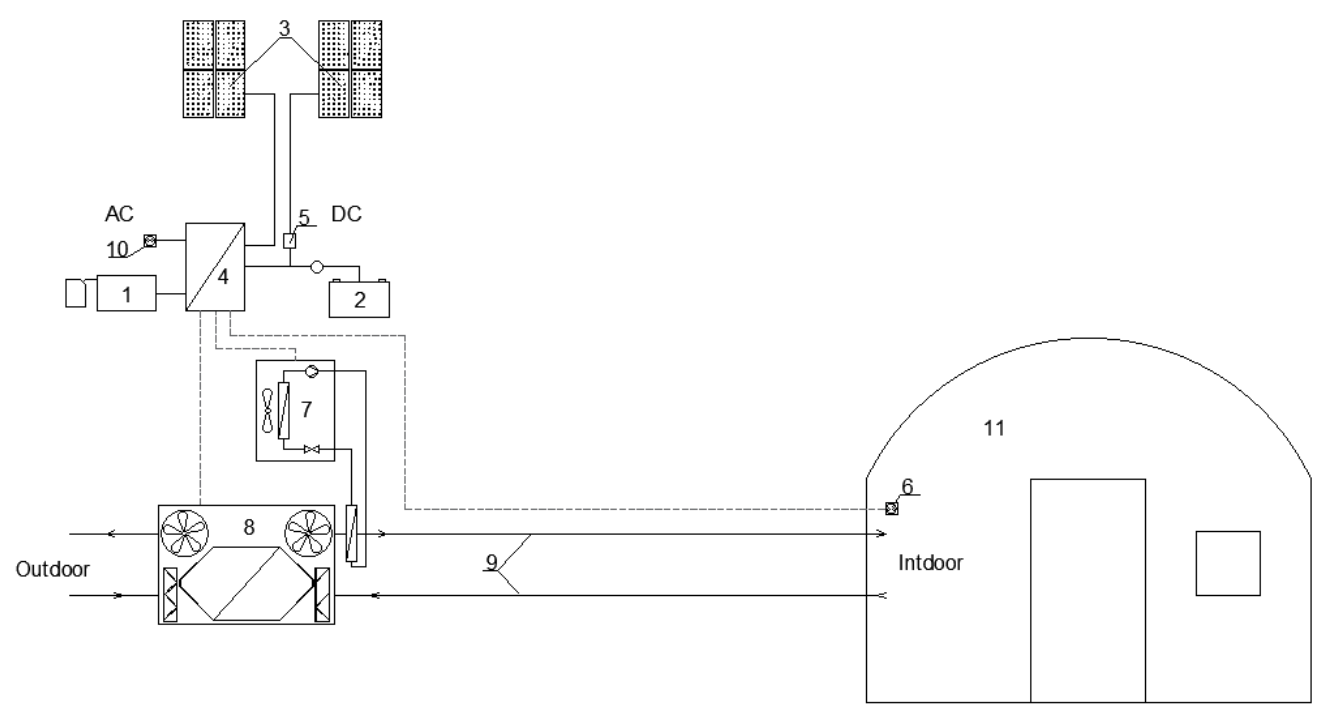

Figure 2. The scheme of the mobile energy generation unit: 1 -diesel generator; 2 -electricity storage battery; 3-PV panels; 4-inverter; 5-controller; 6-electricity consumers' power connector; 7-heat pump; 8-air-to-air heat recovery device; 9-air supply/exhaust channels; 10-connection to the power supply; 11-shelter.

Table 2. Technical characteristics of components of mobile energy generation unit.

\begin{tabular}{|c|c|c|c|}
\hline Component & & Component & \\
\hline PV Batteries & Value & Storage Battery & Value \\
\hline Slope of surface & $0^{\circ}$ & Cell energy capacity & $20 \mathrm{Ah}$ \\
\hline Azimuth of surface & Facing South & Cells in parallel & 6 \\
\hline Short-circuit current & $9.63 \mathrm{~A}$ & Cells in series & 2 \\
\hline Open-circuit voltage & $40.69 \mathrm{~V}$ & Charging efficiency & 0.92 \\
\hline Voltage at Max power point & $33.21 \mathrm{~V}$ & $\begin{array}{l}\text { Max current per } \\
\text { cell charging }\end{array}$ & $100 \mathrm{~A}$ \\
\hline Current at Max power point & $9.23 \mathrm{~A}$ & $\begin{array}{l}\text { Max current per } \\
\text { cell discharge }\end{array}$ & $-200 \mathrm{~A}$ \\
\hline $\begin{array}{c}\text { Temperature coefficient } \\
\text { of ISC }\end{array}$ & $0.00443 \mathrm{~A} / \mathrm{K}$ & Max charge voltage per cell & $2.8 \mathrm{~A}$ \\
\hline $\begin{array}{c}\text { Temperature coefficient } \\
\text { of VOC }\end{array}$ & $-0.141 \mathrm{~V} / \mathrm{K}$ & Inverter & Value \\
\hline $\begin{array}{l}\text { Number of cells wired } \\
\text { in series }\end{array}$ & 60 & Regulator efficiency & 0.98 \\
\hline Module area & $1.46 \mathrm{~m}^{2}$ & $\begin{array}{l}\text { Inverter efficiency } \\
\quad(D C \text { to } A C)\end{array}$ & 0.94 \\
\hline Number of modules in series & 2 & $\begin{array}{l}\text { Inverter efficiency } \\
\text { (AC to DC) }\end{array}$ & 0.94 \\
\hline $\begin{array}{l}\text { Number of modules in } \\
\text { parallel }\end{array}$ & 6 & $\begin{array}{l}\text { High limit on fractional } \\
\text { state of change (FSOC) }\end{array}$ & $100 \%$ \\
\hline Heat pump & Value & Low limit on FSOC & 0 \\
\hline $\begin{array}{l}-20{ }^{\circ} \mathrm{C} \text { outside dry-bulb } \\
\text { temperature }(\mathrm{DBT})\end{array}$ & $\begin{array}{c}\text { Heating capacity } \\
3.52 \mathrm{~kW}\end{array}$ & $\begin{array}{c}\text { Charge to discharge limit } \\
\text { on FSOC }\end{array}$ & 0 \\
\hline $5{ }^{\circ} \mathrm{C}$ intake DBT & $\begin{array}{c}\text { Heating power } \\
1.76 \mathrm{~kW}\end{array}$ & $\begin{array}{l}\text { Inverter output } \\
\text { power capacity }\end{array}$ & $2400 \mathrm{~W}$ \\
\hline $29^{\circ} \mathrm{C}$ outside DBT & $\begin{array}{l}\text { Total cooling } \\
\text { capacity } 3.5 \mathrm{~kW}\end{array}$ & $\begin{array}{l}\text { Current for grid charging } \\
\text { of battery }\end{array}$ & $100 \mathrm{~A}$ \\
\hline $22{ }^{\circ} \mathrm{C}$ intake DBT & $\begin{array}{c}\text { Cooling power } \\
0.95 \mathrm{~kW}\end{array}$ & $\begin{array}{l}\text { Upper limit on FSOC } \\
\text { grid charging }\end{array}$ & $100 \%$ \\
\hline
\end{tabular}


Table 2. Cont.

\begin{tabular}{cccc}
\hline Component & \multicolumn{3}{c}{ Component } \\
\hline Air-to-air heat recovery unit & Value & Diesel generator & Value \\
\hline $\begin{array}{c}\text { Heat recovery sensible } \\
\text { effectiveness }\end{array}$ & 0.797 & Relate power & $2.0 \mathrm{~kW}$ \\
$\begin{array}{c}\text { Heat recovery latent } \\
\text { effectiveness }\end{array}$ & 0.889 & Max power & $2.4 \mathrm{~kW}$ \\
$\begin{array}{l}\text { Ventilation flow rate } \\
\text { Ventilation fan total power }\end{array}$ & $\begin{array}{c}\text { 350 } \mathrm{m}^{3} / \mathrm{h} \\
150 \mathrm{~W}\end{array}$ & Min power & $0.6 \mathrm{~kW}$ \\
\hline
\end{tabular}

\subsection{Experimental Context}

The mobile energy generation unit has been tested in real conditions in Riga, Latvia, for a year. On the campus of the Riga Technical University, the conditions of the temporary shelter were recreated-a tent was set up and a mobile energy generation unit was connected to it (see Figure 3), and the laboratory staff performed the measurements in the tent at in different seasons and times of the day. For the accuracy of the experiment, various electrical devices were connected and the number of people varied from zero to five. Various air temperature sensors and TESTO 480 comfort probes were installed inside the tent to measure the temperature; humidity and indoor air quality (see Figure 4). Technical characteristics of the mobile energy generation unit are described in Table 2.

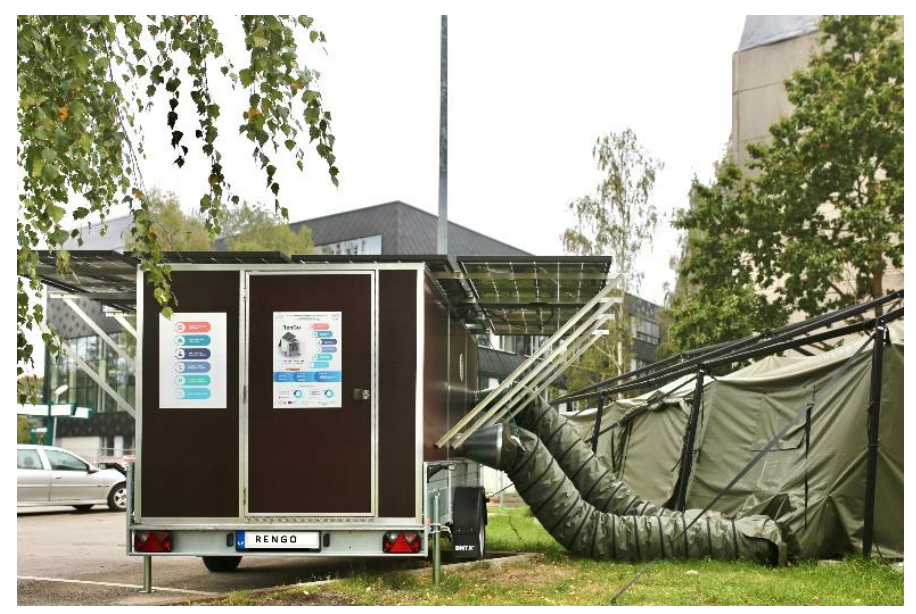

Figure 3. The mobile energy generation unit connected to the tent.

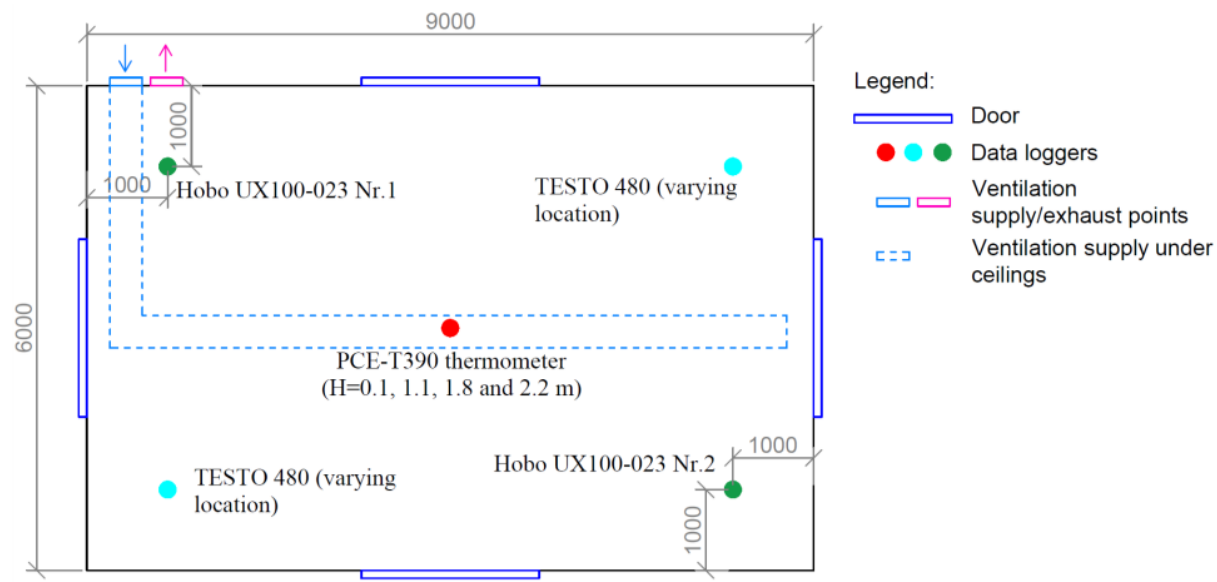

Figure 4. Sensors installation scheme in the tent. 
Based on real measurement data from the recreated temporary shelter, the mobile energy generation unit's sustainability to operate HVAC systems and generate electricity for temporary shelter occupants' needs was evaluated.

\subsection{Theoretical Model}

Experimental study based on the recreated temporary shelter measurement was mirrored by digital modelling. For this purpose a digital model (Figure 5) in transient system simulation (TRNSYS) software was developed.

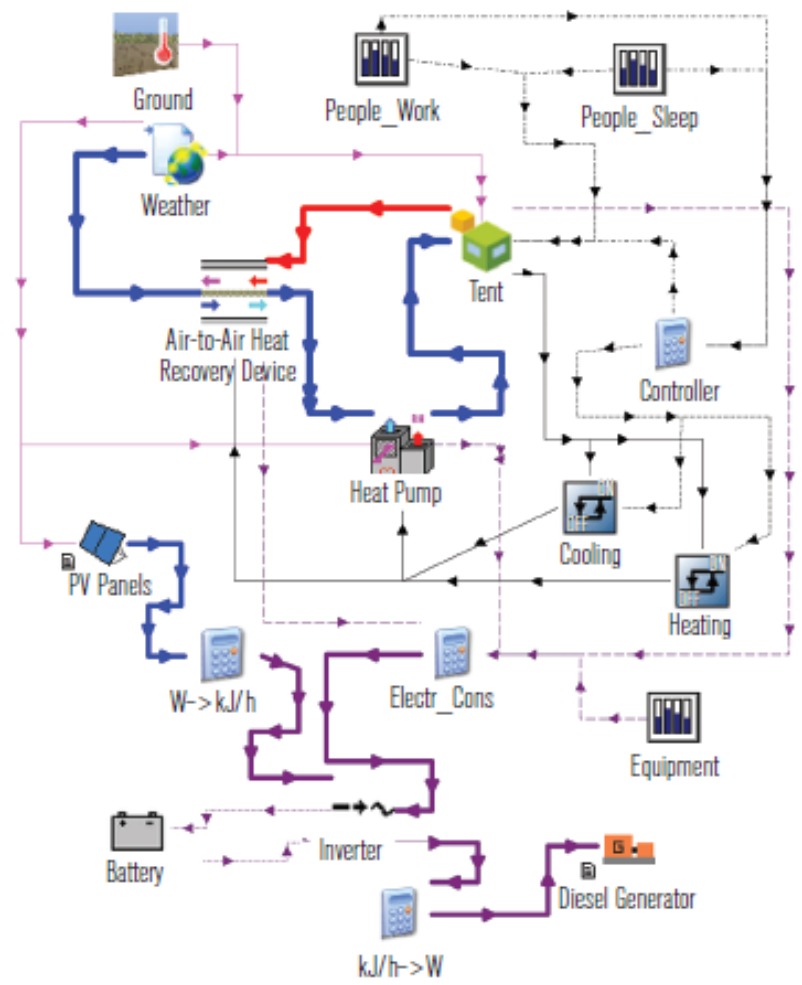

Figure 5. TRNSYS model for mobile energy unit.

The temporary shelter's energy system was simulated based on the following assumptions:

1. System simulations were made for a one-year period for Riga, Latvia climate conditions with 20 s calculation step;

2. Controllers sent on/off signals to heat pump depending on the air temperature in the tent and control precise temperature (for heating or cooling needs) in the tent according to timetable (see Table 3);

3. A comfortable climate for occupants' wellbeing and for the reduction of $\mathrm{CO}_{2}$ in the tent was provided by an air-to-air heat recovery device according to sensor signals, and ventilation was provided only during heating periods;

4. Parameters of the tent were adopted according to the manufacturer's specification (see Table 3);

5. The diesel generator was switched on in cases when additional electricity was required or if the storage battery could not be charged during the day;

6. The electrical load of the system was $\sim 2.3 \mathrm{~kW}$;

7. A digital model observed heat emissions from occupants, lighting and electricity consumption from equipment according to Table 3. 
Table 3. Input data for energy system simulation.

\begin{tabular}{|c|c|c|c|c|c|c|}
\hline \multicolumn{3}{|c|}{ Tent Parameters } & \multicolumn{4}{|c|}{ Value } \\
\hline \multirow{7}{*}{\multicolumn{3}{|c|}{$\begin{array}{c}\text { Roof and wall } \\
\text { Floor } \\
\text { Volume } \\
\text { Area } \\
\text { Heat Loss } \\
\text { Capacitance } \\
\text { Weather }\end{array}$}} & \multicolumn{4}{|c|}{$\mathrm{U}=1.13 \mathrm{~W} / \mathrm{m}^{2} \mathrm{~K}$} \\
\hline & & & \multicolumn{4}{|c|}{$\mathrm{U}=0.87 \mathrm{~W} / \mathrm{m}^{2} \mathrm{~K}$} \\
\hline & & & \multicolumn{4}{|c|}{$35.25 \mathrm{~m}^{3}$} \\
\hline & & & \multicolumn{4}{|c|}{$20 \mathrm{~m}^{2}$ floor; $48.6 \mathrm{~m}^{2}$ walls and roof } \\
\hline & & & \multicolumn{4}{|c|}{$73.32 \mathrm{~W} / \mathrm{K}$} \\
\hline & & & \multicolumn{4}{|c|}{$42.3 \mathrm{~kJ} / \mathrm{K}$} \\
\hline & & & \multicolumn{4}{|c|}{ Riga, Latvia } \\
\hline \multicolumn{7}{|c|}{ Timetable } \\
\hline \multicolumn{3}{|c|}{ Occupant } & \multirow[b]{2}{*}{$\begin{array}{c}\text { Heating } \\
\mathrm{T}\left({ }^{\circ} \mathrm{C}\right)\end{array}$} & \multirow[b]{2}{*}{$\begin{array}{c}\text { Cooling T } \\
\left({ }^{\circ} \mathrm{C}\right)\end{array}$} & \multirow[b]{2}{*}{$\begin{array}{c}\text { Light } \\
\text { (W) }\end{array}$} & \multirow[b]{2}{*}{$\begin{array}{l}\text { Equipment } \\
\text { (W) }\end{array}$} \\
\hline Time & Count & $\begin{array}{c}W \\
\text { (met) }\end{array}$ & & & & \\
\hline 12 a.m.-6 a.m. & 5 & $100(0.9)$ & $18 \pm 2$ & $23 \pm 1$ & - & - \\
\hline 6 a.m.-10 a.m. & 2 & $125(1.1)$ & $18 \pm 2$ & $23 \pm 1$ & 55 & - \\
\hline 10 a.m.-1 p.m. & 0 & - & $5 \pm 2$ & $27 \pm 1$ & - & - \\
\hline 1 p.m.-3 p.m. & 5 & $125(1.1)$ & $18 \pm 2$ & $23 \pm 1$ & 55 & 300 \\
\hline 3 p.m.-8 p.m. & 0 & - & $5 \pm 2$ & $27 \pm 1$ & - & - \\
\hline 8 p.m.-10 p.m. & 5 & $125(1.1)$ & $18 \pm 2$ & $23 \pm 1$ & 55 & 40 \\
\hline 10 p.m.-12 a.m. & 5 & $100(0.9)$ & $18 \pm 2$ & $23 \pm 1$ & - & - \\
\hline
\end{tabular}

TRNSYS model includes all parts of mobile energy unit and allows performing dynamic energy simulations in various climates.

\subsection{Validation of Digital Model}

A digital TRNSYS model was validated based on real measurements carried out during mobile energy unit operation (see Figure 6). A mobile energy unit ensured data logging with $1 \mathrm{~min}$ interval. For the validation, solar radiation on the horizontal surface $\left[\mathrm{W} / \mathrm{m}^{2}\right]$ and total electricity consumption [W] from 22 June 2021 15:00 till 23 June 2021 15:00 was used. During this period the diesel generator was switched off. At the start, the battery was fully charged $(100 \%)$. The power injected to the battery translates into a positive energy balance, while the power going from the battery translates into a negative energy balance.

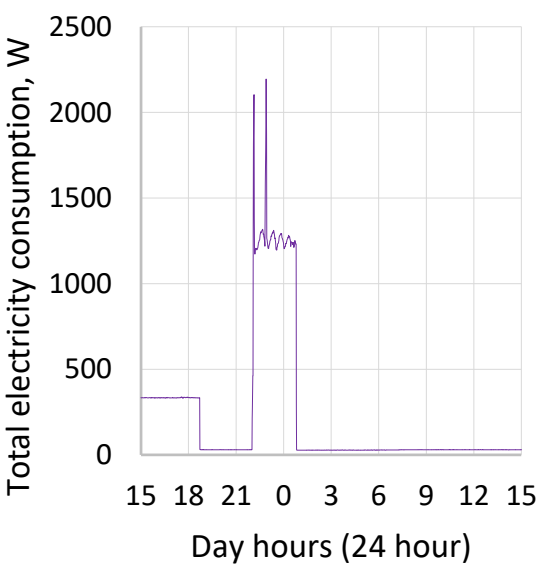

(a)

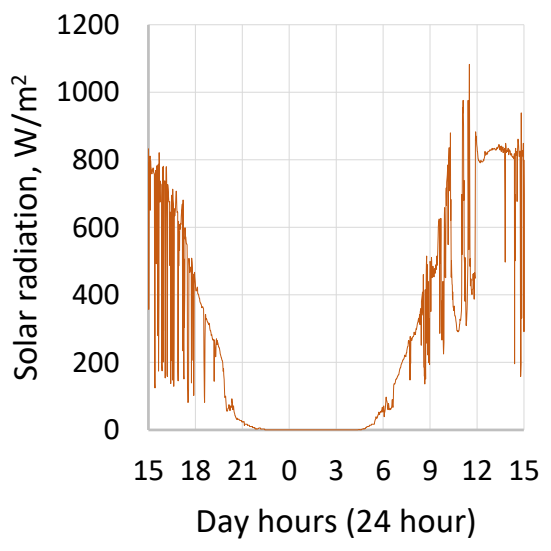

(b)

Figure 6. Cont. 


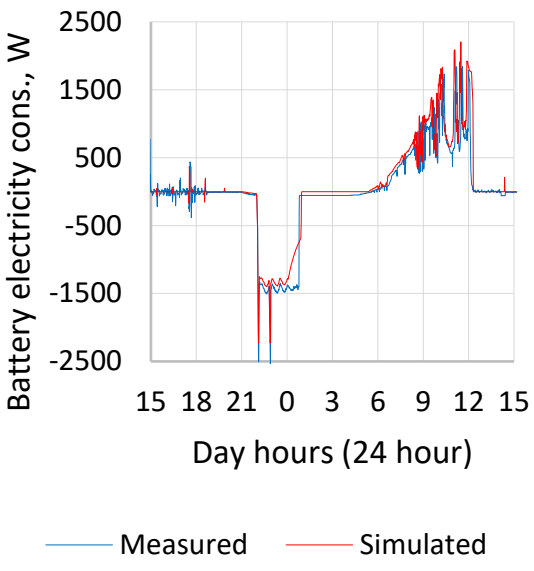

(c)

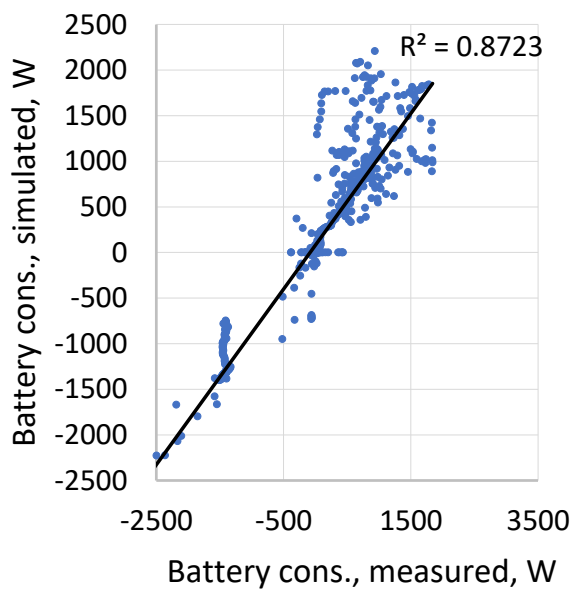

(d)

Figure 6. TRNSYS model validation ((a) real electricity consumption; (b) measured solar radiation; (c) comparison of measured and calculated data; (d) battery capacity).

As can be seen, the TRNSYS model data have a good correlation with measured data. The further evaluation of the system performance is based on the theoretical TRNSYS model.

\section{Results}

By compiling real operating data of the mobile energy generation unit for one year, it turns out that about $60 \%$ of the heat supplied in the winter, spring and autumn seasons (for case of Riga) from the exhaust air is recovered from the air-to-air heat recovery unit [16]. The maximum diesel consumption for supplying the recreated temporary shelter with energy occurred in winter (see Table 4). In most cases in spring, summer and autumn, the electricity produced by the PV was higher than the consumed electricity per day.

Table 4. One-year operational data for Riga, Latvia climate conditions.

\begin{tabular}{ccccc}
\hline & \multicolumn{4}{c}{ Year Seasons } \\
\cline { 2 - 5 } & $\begin{array}{c}\text { Spring } \\
\mathbf{( 2 0 2 0 )}\end{array}$ & $\begin{array}{c}\text { Summer } \\
\mathbf{( 2 0 2 0 )}\end{array}$ & $\begin{array}{c}\text { Autumn } \\
\mathbf{( 2 0 2 0 )}\end{array}$ & $\begin{array}{c}\text { Winter } \\
\mathbf{( 2 0 2 1})\end{array}$ \\
\hline Electricity consumed $(\mathrm{kWh})$ & 4.22 & 5.20 & 354 & 1.001 \\
\hline Diesel generator produced electricity $(\mathrm{kWh})$ & 210 & 60 & 370 & 1.173 \\
\hline Diesel consumed $(\mathrm{l})$ & 70 & 20 & 119 & 378 \\
\hline Diesel generator work time $(\mathrm{h})$ & 193 & 55 & 298 & 955 \\
\hline Recovered heat $(\mathrm{kWh})$ & 1.347 & - & 1.080 & 3.114 \\
\hline Heat from heat pump $(\mathrm{kWh})$ & 804 & - & 687 & 2.104 \\
\hline Waste heat from diesel generator $(\mathrm{kWh})$ & 480 & - & 803 & 2.554 \\
\hline
\end{tabular}

For data validation several simulations were performed in TRNSYS. Digital models developed for a series of cities (Riga, Latvia; Stockholm, Sweden; London, United Kingdom-with similar climate conditions) for demonstration of the PV impact in off-grid case temporary shelter operations. The high energy consumption for heating depends on country-specific climatic conditions, mainly from October to April [31]. The efficiency of solar panels depends on the following factors:

- climatic conditions;

- current lighting (presence or absence of shading);

- possible contamination (soiling, dust cover, etc.);

- the angle of inclination of the elements. 
In our case the most important factor is climate conditions, because the energy generation unit is mobile, therefore the factors, such as the current lighting of the PV and angle of inclination of the PV, can be easily adjusted, and the unit can be easily cleaned of dirt and dust. The average solar radiation in Northern Europe is $1.1 \mathrm{kWh} / \mathrm{m}^{2}$. For the simulated cases see Table 5 (data obtained from the "Global Solar Atlas 2.0" - a free, web-based application is developed and operated by the company Solargis s.r.o. on behalf of the World Bank Group, utilizing Solargis data, with funding provided by the Energy Sector Management Assistance Program (ESMAP). For additional information: https://globalsolaratlas.info (accessed on 26 November 2021) [32]).

Table 5. Average Solar direct normal irradiation (DNI) and Specific photovoltaic power output (PVout).

\begin{tabular}{ccc}
\hline \multirow{2}{*}{ City } & \multicolumn{2}{c}{ Average } \\
\cline { 2 - 3 } & DNI, $\mathbf{k W h} / \mathbf{m}^{\mathbf{2}}$ & PVout, $\mathbf{k W h} \mathbf{k} \mathbf{k} \mathbf{p}$ \\
\hline Riga & 2.79 & 2.87 \\
Stockholm & 2.96 & 2.89 \\
London & 2.29 & 2.74 \\
\hline
\end{tabular}

In the case of Riga (see Table 6) for the electricity supply and HVAC systems operation, the PV system-produced electricity would reduce the diesel fuel consumption for diesel generator operation by $71-93 \%$ in spring and summer seasons and in winter by $9 \%$.

Table 6. PV panels impact in case of Riga.

\begin{tabular}{ccccc}
\hline & & $\begin{array}{c}\text { Produced } \\
\text { Electricity, kWh }\end{array}$ & \multicolumn{2}{c}{$\begin{array}{c}\text { Diesel Fuel } \\
\text { Consumption, 1 }\end{array}$} \\
\hline \multirow{2}{*}{ Spring, 2020 } & Without PV & 0 & 241 & - \\
& PV & 797 & 70 & $-71 \%$ \\
\hline \multirow{2}{*}{ Summer, 2020 } & Without PV & 0 & 300 & - \\
& PV & 1203 & 20 & $-93 \%$ \\
\hline \multirow{2}{*}{ Autumn, 2020 } & Without PV & 0 & 205 & - \\
& PV & 286 & 119 & - \\
\hline \multirow{2}{*}{ Winter, 2021 } & Without PV & 0 & 416 & $-9 \%$ \\
\hline
\end{tabular}

Analyzing the simulation results, the electricity required for the equipment load and HVAC system operation of the temporary shelter mobile energy generation unit can provide off-grid work by approximately $54 \%$ without diesel generator. In summer, this increases to approximately $93 \%$. Table 7 presents simulation data for four cities with similar climate conditions, where more heating is needed than cooling.

Table 7. Summary of an annual operation of mobile energy unit in similar climate conditions.

\begin{tabular}{cccccccccc}
\hline & \multicolumn{3}{c}{ Electricity, kWh } & \multicolumn{3}{c}{ Energy, kWh } & \multicolumn{2}{c}{ Time, h } \\
\cline { 2 - 9 } Town & $\begin{array}{c}\text { Total } \\
\text { Required }\end{array}$ & $\begin{array}{c}\text { PV Pro- } \\
\text { duced }\end{array}$ & $\begin{array}{c}\text { Additional } \\
\text { Required }\end{array}$ & $\begin{array}{c}\text { Heat Re- } \\
\text { covered }\end{array}$ & $\begin{array}{c}\text { Heat } \\
\text { Supplied }\end{array}$ & $\begin{array}{c}\text { Cool } \\
\text { Supplied }\end{array}$ & Heating & Cooling & $\begin{array}{c}\text { Diesel } \\
\text { Work }\end{array}$ \\
\hline Stockholm & 1968 & 2313 & 1639 & 5585 & 3669 & 392 & 1626 & 115 & 1369 \\
$\begin{array}{c}\text { (Sweden) } \\
\text { Riga (Latvia) }\end{array}$ & 1989 & 2268 & 1674 & 5571 & 3616 & 457 & 1600 & 134 & 1460 \\
London (UK) & 944 & 2169 & 577 & 1895 & 1152 & 559 & 609 & 165 & 412 \\
\hline
\end{tabular}

The electricity output $(\mathrm{kWh})$ generated by the PV is higher than the consumed electricity (kWh). However, it is highly dependent on the optimal HVAC system operation algorithms - different types of camps/shelters, number of occupants, equipment loads, etc. 
Studying the locations of the world's 10 Largest Refugee Camps-Kakuma, Hagadera, Ifo and Dagahaley in Kenya; Zaatari in Jordan; Yida in South Sudan; Katumba and Mishamo in Tanzania; Pugnido in Ethiopia; and Panian in Pakistan [33]—digital models were created for the simulation of mobile energy unit possible use in the climatic conditions of these camps. Simulations were made under the assumptions described in Section 2.2. In addition, climate conditions were simulated according to the location of existing largest refugee camps. For digital model creation, the TRNSYS climatic database was used. To assess the impact of PV panels for electricity production and HVAC system operation in temporary camp, two models were created: Case 0: without PV panels (only with diesel generator); Case 1: with PV panels + diesel generator (see Table 8).

Table 8. Summary of an annual operation of mobile energy unit in the world's 10 Largest Refugee Camps climate conditions.

\begin{tabular}{|c|c|c|c|c|c|c|c|c|}
\hline Case & $\begin{array}{c}\text { Town, } \\
\text { TRNSYS }\end{array}$ & $\begin{array}{c}\text { Average } \\
\text { Air } \\
\mathbf{T}^{\circ} \mathrm{C}\end{array}$ & $\begin{array}{l}\text { PV Prod. } \\
\text { el, kWh }\end{array}$ & $\begin{array}{c}\text { Diesel Fuel } \\
\text { Cons., } 1\end{array}$ & $\begin{array}{l}\text { Heating } \\
\text { Time, h }\end{array}$ & $\begin{array}{l}\text { Cooling } \\
\text { Time, h }\end{array}$ & $\begin{array}{c}\text { Diesel } \\
\text { Generator } \\
\text { Work Time, } \mathrm{h}\end{array}$ & $\begin{array}{c}\text { Reduction of } \\
\text { Diesel Fuel } \\
\text { Consumption, \% }\end{array}$ \\
\hline 0 & Garissa & \multirow{2}{*}{29.2} & 0 & 2402 & 0 & 5426 & 6011 & \multirow[b]{2}{*}{57} \\
\hline 1 & (Kenya) & & 4732 & 1033 & 0 & 5426 & 2577 & \\
\hline 0 & Jerusalem & \multirow{2}{*}{16.1} & 0 & 1247 & 185 & 1153 & 3211 & \multirow[b]{2}{*}{96} \\
\hline 1 & (Israel) & & 4769 & 56 & 190 & 1152 & 135 & \\
\hline 0 & Malakal & \multirow{2}{*}{28.0} & 0 & 2117 & 0 & 4367 & 5374 & \multirow[b]{2}{*}{61} \\
\hline 1 & (South Sudan) & & 4417 & 827 & 0 & 4367 & 2092 & \\
\hline 0 & Kigoma & \multirow{2}{*}{23.5} & 0 & 1654 & 0 & 2340 & 4439 & \multirow[b]{2}{*}{65} \\
\hline 1 & (Tanzania) & & 3588 & 577 & 0 & 2340 & 1627 & \\
\hline 0 & Addis Ababa & \multirow{2}{*}{16.6} & 0 & 947 & 38 & 762 & 2375 & \multirow[b]{2}{*}{94} \\
\hline 1 & (Ethiopia) & & 4496 & 54 & 41 & 762 & 145 & \\
\hline 0 & Peshawar & \multirow{2}{*}{22.6} & 0 & 1697 & 56 & 3125 & 4256 & \multirow[b]{2}{*}{69} \\
\hline 1 & (Pakistan) & & 4213 & 519 & 56 & 3125 & 1293 & \\
\hline
\end{tabular}

As seen from the Table 9 (data obtained from the "Global Solar Atlas 2.0 [32]), all of the world's largest refugee camps are located in regions with rather similar climatic conditions with respect to solar direct normal irradiation. The cooling duration to ensure occupant comfort and wellbeing varies from $762-5426 \mathrm{~h}$ annually, while the heating duration is far less-40-190 $\mathrm{h}$ annually (see Table 10).

The electricity output generated by the PV panels is higher (in most cases) than the total required electricity amount for recreated temporary camps.

Table 9. Average Solar direct normal irradiation (DNI) and Specific photovoltaic power output (PVout).

\begin{tabular}{ccc}
\hline \multirow{2}{*}{ City } & \multicolumn{2}{c}{ Average } \\
\cline { 2 - 3 } & DNI, $\mathbf{k W h} / \mathbf{m}^{\mathbf{2}}$ & PVout, $\mathbf{k W h} \mathbf{k} \mathbf{k W} \mathbf{p}$ \\
\hline Garissa & 4.01 & 4.3 \\
Jerusalem & 5.97 & 4.85 \\
Malakal & 4.18 & 4.42 \\
Kigoma & 4.33 & 4.46 \\
Addis Ababa & 4.82 & 4.7 \\
Peshawar & 3.97 & 4.25 \\
\hline
\end{tabular}


Table 10. PV produced and consumed electricity amount.

\begin{tabular}{cccc}
\hline Town, TRNSYS & $\begin{array}{c}\text { Total Required } \\
\text { el, kWh }\end{array}$ & $\begin{array}{c}\text { PV Produced } \\
\text { el, kWh }\end{array}$ & $\begin{array}{c}\text { Difference, \% (PV Produced } \\
\text { Electricity/Electricity } \\
\text { Consumed) }\end{array}$ \\
\hline Garissa (Kenya) & 6057 & 4732 & 78 \\
Jerusalem (Israel) & 1659 & 4769 & 287 \\
Malakal (South Sudan) & 4900 & 4417 & 90 \\
Kigoma (Tanzania) & 2766 & 3588 & 130 \\
Addis Ababa (Ethiopia) & 1163 & 4496 & 387 \\
Peshawar (Pakistan) & 3694 & 4213 & 114 \\
\hline
\end{tabular}

\section{Discussion}

Despite the overall globalization and the growing number of people living in cities, many regions worldwide still suffer from an unreliable and inconsistent energy supply. Energy blackouts can have a significant impact on occupant safety, health and wellbeing. As such, fast deployable energy efficient mobile energy supply solutions should be introduced more widely. While it is not necessary to produce dozens of units, more reliable technological solutions of mobile energy units that are readily available for mass production should be developed. Thus, in case of emergency these units can be immediately put into production.

\section{Conclusions}

With over 6.6 million refugees and displaced people living in camps (temporary shelters) [2], often in extreme climatic conditions, it must be ensured that these camps provide adequate living conditions that are compatible with basic standards with regards to human safety, wellbeing and hygiene.

In response, this paper introduces a mobile energy generation unit with integrated PV panels, a heat pump and an air-to-air heat recovery device to ensure adequate air hygiene and occupants' comfort in temporary camps. Two modifications were examined-one using a physical prototyping (recreating a small-scale temporary shelter) and the other using simulations based on real data for different climatic conditions.

Looking at the efficiency of the recreated temporary mobile energy generation shelters, it can be concluded that such units can provide a sufficient amount of electricity in an off-grid setting. The modeling results also showed how the use of a PV-based mobile energy generation unit could significantly reduce diesel fuel consumption in temporary camps/shelters from $54 \%$ per year (in Riga, Latvia) to $96 \%$ per year (in Jerusalem, Israel). The PV-generated electricity output is higher (in most cases) than the consumed electricity amount. The main advantage of such installation is its mobility, which makes it possible to move it without hindrance, and thus, if necessary, track the sun and clean the PV from dirt and dust, as well as relocate it using a regularly sized vehicle. Moreover, if the intensity of solar radiation is not sufficient or if the required electricity output increases, the accumulated energy from the storage batteries or a diesel generator for electricity production can be used, to ensure consistent supply of the necessary energy for temporary camps/shelters in off-grid conditions.

Author Contributions: Conceptualization, A.B. and K.L.; methodology, D.Z.; software, R.B.; validation, K.L., D.Z. and R.B.; formal analysis, D.Z.; investigation, A.B., K.L. and D.Z.; data curation, K.L.; writing-original draft preparation, A.B.; writing-review and editing, A.B., D.Z. and K.L.; visualization, R.B.; supervision, A.B. All authors have read and agreed to the published version of the manuscript. 
Funding: This study was supported by: the European Regional Development Fund project No. 1.1.1.1/16/A/048 "Nearly Zero Energy Solutions for Unclassified Buildings", Riga Technical University's Doctoral Grant programme DOK.BIF/20 and EIC Manufacturing Grant "Mobile energy supply unit-RENGO".

Informed Consent Statement: Not applicable.

Conflicts of Interest: The authors declare no conflict of interest.

\section{References}

1. Coronavirus: Italian Patients Treated in Tents and Warehouse 2020. BBC News, 13 March 2020.

2. UNHCR Global Trends Forced Displacement in 2020; UNHCR: Geneva, Switzerland, 2020.

3. UNHCR Global Trends UNHCR: Global Trends Forced Displacement in 2018; UNHCR: Geneva, Switzerland, 2019.

4. NATO. Operations and Missions: Past and Present; NATO: Brussels, Belgium, 2021.

5. Prozuments, A.; Staveckis, A.; Zemitis, J.; Bajare, D. Evaluation of Heating and Cooling Loads for a Well-Insulated Single-Family House under Variable Climate Pattern. Environ. Clim. Technol. 2021, 25, 750-763. [CrossRef]

6. Prozuments, A.; Borodinecs, A.; Zemitis, J. Survey Based Evaluation of Indoor Environment in an Administrative Military Facility. J. Sustain. Archit. Civ. Eng. 2020, 27, 96-107. [CrossRef]

7. NPR The NPR Daily Newsletter. Available online: https:/ /www.npr.org/2011/06/25/137414737/among-the-costs-of-war-20bin-air-conditioning (accessed on 26 November 2021).

8. NATO. NATO's Science for Peace and Security (SPS) Programme: The SPS project "Camp Energy Efficiency"; NATO: Brussels, Belgium, 2018. Available online: https://www.nato.int/cps/en/natohq/news_158964.htm (accessed on 26 November 2021).

9. NATO. Secretary General's Annual Report 2019; NATO: Brussels, Belgium, 2020.

10. Neves, D.; Baptista, P.; Pires, J.M. Sustainable and inclusive energy solutions in refugee camps: Developing a modelling approach for energy demand and alternative renewable power supply. J. Clean. Prod. 2021, 298, 126745. [CrossRef]

11. van Hove, E.; Johnson, N.G. Refugee settlements in transition: Energy access and development challenges in Northern Uganda. Energy Res. Soc. Sci. 2021, 78, 102103. [CrossRef]

12. Pearson, J.; Wagner, T.; Delorit, J.; Schuldt, S. Meeting Temporary Facility Energy Demand with Climate-Optimized Off-Grid Energy Systems. IEEE Open Access J. Power Energy 2020, 7, 203-211. [CrossRef]

13. Moore, B. Refugee settlements and sustainable planning. Forced Migr. Rev. 2017. Available online: https://www.fmreview.org/ sites/fmr/files/FMRdownloads/en/shelter/moore.pdf (accessed on 23 October 2021).

14. Lehne, J.; Blyth, W.; Lahn, G.; Bazilian, M.; Grafham, O. Energy services for refugees and displaced people. Energy Strateg. Rev. 2016, 13, 134-146. [CrossRef]

15. Lahn, G.; Grafham, O. Heat, Light and Power for Refugees: Saving Lives, Reducing Costs; Chatham House, the Royal Institute of International Affairs: London, UK, 2015; p. 69.

16. Bogdanovics, R.; Borodinecs, A.; Zemitis, J.; Zajacs, A. Using a mobile modular energy unit with PV panels for heating. ASHRAE J. 2021, 63, 38-46.

17. Raghuwanshi, S.S.; Arya, R. Reliability evaluation of stand-alone hybrid photovoltaic energy system for rural healthcare centre. Sustain. Energy Technol. Assessments 2020, 37, 100624. [CrossRef]

18. Dedović, M.M.; Avdaković, S.; Mujezinović, A.; Dautbašić, N. Integration of pv into the sarajevo canton energy system-air quality and heating challenges. Energies 2021, 14, 123. [CrossRef]

19. Liu, Y.; Wang, Y.; Luo, X. Design and operation optimization of distributed solar energy system based on dynamic operation strategy. Energies 2021, 14, 69. [CrossRef]

20. Zajacs, A.; Bogdanovics, R.; Borodinecs, A. Analysis of low temperature lift heat pump application in a district heating system for flue gas condenser efficiency improvement. Sustain. Cities Soc. 2020, 57, 102130. [CrossRef]

21. Duman, A.C.; Güler, Ö. Techno-economic analysis of off-grid PV/wind/fuel cell hybrid system combinations with a comparison of regularly and seasonally occupied households. Sustain. Cities Soc. 2018, 42, 107-126. [CrossRef]

22. Islam, M.M.; Sun, Z. Onsite generation system sizing for manufacturing plant considering renewable sources towards sustainability. Sustain. Energy Technol. Assess. 2019, 32, 1-18. [CrossRef]

23. El Zein, M.; Gebresenbet, G. Investigating off-grid systems for a mobile automated milking facility. Heliyon 2021, 7, e06630. [CrossRef] [PubMed]

24. Franceschi, J.; Rothkop, J.; Miller, G. Off-grid solar PV power for humanitarian action: From emergency communications to refugee camp micro-grids. Procedia Eng. 2014, 78, 229-235. [CrossRef]

25. Prompinit, K.; Plangklang, B.; Hiranvarodom, S. Design and construction of a mobile PV hybrid system prototype for isolated electrification. Procedia Eng. 2011, 8, 138-145. [CrossRef]

26. Obydenkova, S.V.; Pearce, J.M. Technical viability of mobile solar photovoltaic systems for indigenous nomadic communities in northern latitudes. Renew. Energy 2016, 89, 253-267. [CrossRef]

27. The International Renewable Energy Agency (IRENA). Renewables for Refugee Settlements Sustainable Energy Access in Humanitatian Situations; International Renewable Energy Agency: Abu Dhabi, United Arab Emirates, 2019; p. 52.

28. Fasulo, L. The 2030 Agenda for Sustainable Development. In An Insider's Guide to the UN; Yale University Press: London, UK, 2020. 
29. Borodinecs, A.; Prozuments, A.; Zajacs, A.; Zemitis, J. Retrofitting of fire stations in cold climate regions. Mag. Civ. Eng. 2019, 90, 85-92. [CrossRef]

30. Plavenieks, G.; Lesinskis, A.; Dimdina, I. Case Study of Indoor Air Quality and Energy Efficiency in Passive House in Latvia. In Proceedings of the REHVA Annual Conference 2015, Riga, Latvia, 6-9 May 2015.

31. Shipkovs, P.; Kashkarova, G.; Snegirjovs, A.; Vanags, M.; Lebedeva, K.; Shipkovs, J.; Migla, L. Investigations of solar collector's in latvian conditions. Renew. Energy Power Qual. J. 2011, 1. [CrossRef]

32. Global Solar Atlas Global Solar Atlas v2.6. Available online: https:/ / globalsolaratlas.info/map (accessed on 20 October 2021).

33. UNHCR, the UN Refugee Agency. Available online: https://storymaps.esri.com/stories/2016/refugee-camps/\# (accessed on 3 November 2021). 